\title{
Time needed to schedule dermatological consultations in Brazil ${ }^{*}$ Tempo para agendamento de consultas dermatológicas no Brasil
}

\author{
Hélio Amante Miot $^{1}$
}

\author{
Luciane Donida Bartoli Miot ${ }^{2}$
}

\begin{abstract}
BACKGROUND: It is not clear what the population's demand for dermatologists is, nor how many professionals are needed in order to provide adequate care in this area of expertise. Knowledge of the flow of patients at dermatological clinics throughout the country allows for the formation of expansion and distribution policies regarding professionals, and provides backing for the decision to increase medical residency places. OBJECTIVEs: To evaluate the time it takes to schedule a private dermatological consultation in Brazil, and other factors concerning consultations. METHODS: Survey with a random sample of $14 \%$ of Brazilian dermatologists, simulating the scheduling of emergency clinical and cosmetic consultations, and botulinum toxin procedures. Also, details relating to cost and professionals, were studied. Data were adjusted for each region of the country. RESULTS: A total of 873 dermatologists were evaluated. Full SBD members represented $85 \%$, and $66 \%$ were women. The median time to schedule a consultation ranged from 6 (out-of-pocket payment) to 7 (medical insurance) consecutive working days. Times varied depending on the region. A multivariate analysis showed that out-of-pocket consultations and procedures were scheduled sooner than with medical insurance, regardless of whether they were clinical or cosmetic. CONCLUSION: The characteristics of dermatologists are varied throughout regions of the country. Private consultations and procedures are scheduled sooner than with insurance companies.
\end{abstract}

Keywords: Answering services; Scheduling consultations; Dermatology; Health care surveys; Population surveys; Referral and consultation

Resumo: FunDAMENTOS: Não é clara a demanda populacional dermatológica, assim como a proporção de profissionais adequada para a cobertura de saúde na especialidade. O conhecimento da realidade de fluxo de atendimentos nos consultórios dermatológicos do País permite a formação de políticas de expansão e distribuição de profissionais, além de subsidiar a decisão de ampliação das vagas de residência médica. OBjETIVos: Avaliar o tempo para agendamento de consulta dermatológica privada no Brasil e características ligadas à consulta. MÉTODOs: Inquérito populacional com amostra probabilística de 14\% dos consultórios dermatológicos brasileiros, simulando o agendamento de consulta clínica de urgência, cosmiátrica e aplicação de toxina botulínica. Avaliaram-se também aspectos ligados ao custo e ao profissional. Dados foram ajustados para cada região do País. ResultAdOS: Foram avaliados 873 dermatologistas brasileiros. Sócios titulares da SBD foram 85\% e mulheres, $66 \%$. O tempo mediano para agendamento de consulta variou de 6 (particulares) a 7 (convênios) dias úteis consecutivos, esse valores variaram entre as regiões do País. A análise multivariada demonstrou que atendimentos e procedimentos particulares foram agendados mais rapidamente que os de convênios, independentemente, se clínico ou cosmiátrico. Conclusão: Características dos dermatologistas variaram entre as regiões do País. Consultas e procedimentos particulares são agendados mais brevemente que consultas de convênios.

Palavras-chave: Agendamento de consultas; Dermatologia; Inquéritos demográficos; Pesquisas sobre serviços de saúde; Referência e Consulta; Serviços de atendimento

Received on 01.08.2012.

Approved by the Advisory Board and accepted for publication on 14.10.2012.

* Study carried out in the Departament of Dermatology and Radiotherapy at the Medical School of the State University of São Paulo (Júlio de Mesquita Filho) (Unesp) - Botucatu (SP), Brazil.

Financial Support: None

Conflict of Interest: None

PhD - Assistant Professor in the Departament of Dermatology and Radiotherapy at the Medical School of the State University of São Paulo (Júlio de Mesquita Filho) (Unesp) - Botucatu (SP), Brazil.

PhD - Dermatologist in the Departament of Dermatology and Radiotherapy at the Medical School of the State University of São Paulo (Júlio de Mesquita Filho) (Unesp) - Botucatu (SP), Brazil. 


\section{INTRODUCTION}

It is not clear what the demand for dermatological services is among the Brazilian population, nor how many professionals are needed to provide adequate care in this domain. ${ }^{1}$ The Brazilian Ministry of Health has deemed that there should be one dermatologist for every 80,000 citizens for dermatological and leprosy care, provided by the SUS (Unified Health System, the Brazilian public health system). ${ }^{2}$ In countries with hierarchically organized health systems, such as the UK, the expected number is one dermatologist for every 100,00 citizens. ${ }^{3}$ On the other hand, in metropolitan areas with spontaneous demand for medical care, like in the US, there can be up to one dermatologist for every 20,000 patients. ${ }^{1,45}$

The Brazilian Dermatological Society (SBD) is the second largest dermatological society in the world, with 6,053 registered members (data from 2011), averaging one dermatologist for every 32,000 citizens. However, distribution throughout the country and the states is irregular, being concentrated in metropolitan areas. ${ }^{6,7}$ Further, the SBD has grown by $400-500$ members per year $(6-8 \%)$, at a faster rate than the Brazilian population (1-1.5\%), during the last decade. ${ }^{6-8}$

Knowledge of the flow of patients at dermatological consultations throughout the country allows for the formation of expansion and distribution policies regarding professionals, and provides backing for the decision to increase medical residency places.

The authors seek to estimate the time taken to arrange dermatological consultations in the private system in different regions of the country and, as a secondary aim, to examine matters regarding dermatologists, the cost of consultations, and differences linked to particular types of cutaneous issues.

\section{METHODS}

The article adopts a cross-sectional method of inquiry, involving a random sample (stratified into regions of the country) of dermatologists, drawing on SBD membership data as per the website (http://www.sbd.org.br), between February $21^{\text {st }}$ and August $8^{\text {th }}$, 2011. Sampling involved a table of random numbers, corresponding to the dimensioning for each stratum, applied according to the alphabetical order of the names listed on the SBD website.

A couple of trained actors, in accordance with the randomization, called the clinics of every professional to try and arrange cosmetic (actress) and clinical (actor), consultations. They inquired about insurance agreements, private consultations and aesthetic procedures (Chart 1).

Values (median and interquartile deviations) for the number of consecutive working days for scheduling are discussed in relation to regional characteristics, city population, age, gender, type of member, type of consultation (insurance or private), cost of consultation, type of issue (clinical or cosmetic) and procedure (botulinum toxin).

Proportions among regions were compared using the chi-squared test and residue analysis (standardized and adjusted) of the contingency table. A bivariate comparison was undertaken of the cost of private consultations throughout the regions using a generalized linear model (distribution range), as well as the times for scheduling, using a counting model (negative binomial regression). The multivariate analysis of the times for scheduling consultations was carried out on the basis of a mixed-effects counting model (negative binomial regression). ${ }^{9}$

The significant, two-tailed value of $p<0,05$, was adopted. Data were analyzed using the SPSS 20 software. ${ }^{10}$

The sample size was determined via a pre-test of 50 dermatologists, taking into account a standard error of $\pm 3,0 \%$, an alpha of 0,05 , and power of 0,8 , corrected for the finite universe of each region (Table 1). ${ }^{11}$

\section{RESULTS}

1756 telephone calls were made to 873 Brazilian dermatological clinics $(14,4 \%)$, SBD members, and inquiries were made regarding scheduling times for clinical (urgent), cosmetic and botulinum toxin consultations.

Table 1 outlines the various densities of dermatologists in different Brazilian states.

Table 2 shows demographic data and scheduling times for dermatological consultations and procedures in different regions of the country, noting regional differences with regard to all the variables studied.

Over $40 \%$ of the dermatologists were under 40 . Women and full members represented the youngest age group, even when broken down by region $(p<0,01)$ (Graph 1).

Most of the medical consultations varied in price from $R \$ 150$ to $R \$ 250$, involving considerable regional variation, as the higher prices were generally in the southeast and southwest regions (Table 2). The cost distribution of the medical consultations sampled is outlined in graph 2 . Higher consultation costs were associated with dermatologists who were full SBD members, operating in cities with higher populations, offering exclusive, private care, from a higher age bracket, and who carried out botulinum toxin procedures $(p<0,01)$.

Over half the bookings took place between 2 to 15 working days, involving significant regional variation, with shorter waiting times in the north and northeast, in accordance with the type of service in question (Table 2 and Graph 3). Private consultations and proce- 
CHART 1: Telephone approach used by actors

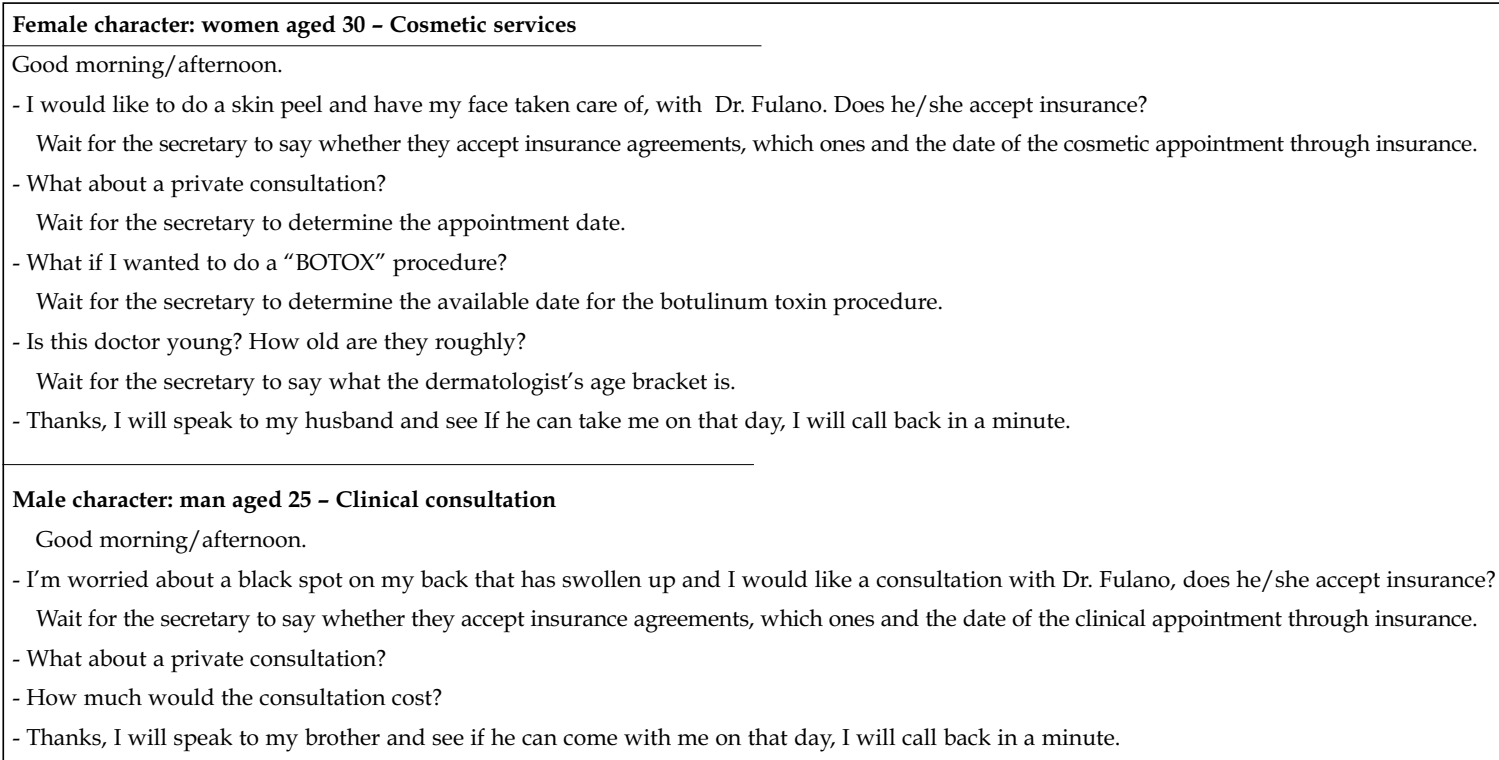

TABLE 1: Demographic distribution of Brazilian dermatologists who are SBD members and sample details

\begin{tabular}{|c|c|c|c|c|c|c|}
\hline Region & Members* & $\begin{array}{l}\text { Sample } \\
\text { N (\% dos sócios) }\end{array}$ & State & Members & Sample & Dermatologists per citizen ${ }^{* *}$ \\
\hline \multirow{3}{*}{ South } & \multirow{3}{*}{853} & \multirow{3}{*}{$170(20)$} & RS & 374 & 62 & 28.598 \\
\hline & & & PR & 299 & 49 & 34.915 \\
\hline & & & SC & 180 & 59 & 34.720 \\
\hline \multirow[t]{4}{*}{ Southeast } & \multirow[t]{4}{*}{3805} & \multirow[t]{4}{*}{$334(9)$} & SP & 2032 & 166 & 20.301 \\
\hline & & & RJ & 1089 & 93 & 14.686 \\
\hline & & & MG & 518 & 48 & 37.829 \\
\hline & & & ES & 166 & 27 & 21.161 \\
\hline \multirow[t]{4}{*}{ Center-West } & \multirow[t]{4}{*}{402} & \multirow[t]{4}{*}{$113(28)$} & DF & 157 & 36 & 16.325 \\
\hline & & & GO & 145 & 32 & 41.407 \\
\hline & & & MT & 59 & 25 & 51.424 \\
\hline & & & MS & 41 & 20 & 59.740 \\
\hline \multirow[t]{9}{*}{ Northeast } & \multirow[t]{9}{*}{789} & \multirow[t]{9}{*}{$186(24)$} & BA & 198 & 43 & 70.815 \\
\hline & & & PE & 197 & 38 & 44.650 \\
\hline & & & CE & 116 & 22 & 72.828 \\
\hline & & & PB & 65 & 14 & 57.951 \\
\hline & & & $\mathrm{RN}$ & 62 & 12 & 51.099 \\
\hline & & & $\mathrm{AL}$ & 56 & 20 & 55.731 \\
\hline & & & SE & 38 & 15 & 54.422 \\
\hline & & & PI & 32 & 11 & 97.469 \\
\hline & & & MA & 25 & 11 & 262.787 \\
\hline \multirow{7}{*}{ North } & \multirow{7}{*}{204} & \multirow{7}{*}{$70(34)$} & PA & 93 & 15 & 81.592 \\
\hline & & & $\mathrm{AM}$ & 66 & 21 & 52.741 \\
\hline & & & RO & 16 & 11 & 97.531 \\
\hline & & & TO & 15 & 13 & 92.230 \\
\hline & & & $\mathrm{AC}$ & 6 & 5 & 122.132 \\
\hline & & & $\mathrm{RR}$ & 4 & 3 & 112.807 \\
\hline & & & $\mathrm{AP}$ & 4 & 2 & 167.172 \\
\hline TOTAL & 6053 & 873 (14) & & & & 31.510 \\
\hline
\end{tabular}

* Data from February 2011;** State population based on the 2010 census. 
TABLE 2: Description and bivariate analysis of the main demographic characteristics of the dermatologists studied and scheduling times for medical consultations

\begin{tabular}{|c|c|c|c|c|c|c|c|}
\hline \multicolumn{2}{|c|}{ Variable } & \multicolumn{6}{|c|}{ Region N(\%) } \\
\hline & & \multirow{3}{*}{$\begin{array}{l}\mathbf{N}(\%) \\
873 \\
721(83)\end{array}$} & \multirow{3}{*}{$\begin{array}{l}\text { South } \\
170 \\
149(88)\end{array}$} & \multirow{3}{*}{$\begin{array}{l}\text { Southeast } \\
334 \\
286(86)\end{array}$} & \multirow{3}{*}{$\begin{array}{l}\text { Center-west } \\
113 \\
97(86)\end{array}$} & \multirow{3}{*}{$\begin{array}{l}\text { Northeast } \\
186 \\
138(74)^{*}\end{array}$} & \multirow{3}{*}{$\begin{array}{l}\text { North } \\
70 \\
51(73)^{*}\end{array}$} \\
\hline & & & & & & & \\
\hline Type of member & Full & & & & & & \\
\hline Gender & Female & $610(70)$ & $116(68)$ & $246(74)$ & $76(67)$ & $131(70)$ & $41(59)^{*}$ \\
\hline \multirow[t]{5}{*}{ Age bracket (years) } & $21-30$ & $23(3)$ & $8(5)$ & $5(2)$ & $7(7)^{*}$ & $2(2)$ & $1(2)$ \\
\hline & $31-40$ & $292(40)$ & $63(43)$ & $113(42)$ & $48(47)$ & $49(32)^{*}$ & $19(33)$ \\
\hline & $41-50$ & $190(26)$ & $35(24)$ & $75(28)$ & $25(25)$ & $45(29)$ & $10(17)$ \\
\hline & $51-60$ & $157(22)$ & $31(21)$ & $55(21)$ & $11(11)$ & $42(27)^{*}$ & $18(31)$ \\
\hline & $>60$ & $66(9)$ & $10(7)$ & $19(7)$ & $11(11)$ & $16(10)$ & $10(17)^{*}$ \\
\hline \multirow[t]{4}{*}{ Population (1000 cit) } & $<100$ & $66(8)$ & $26(15)^{*}$ & $17(5)$ & $11(10)$ & $4(2)$ & $8(11)$ \\
\hline & $101-300$ & $119(14)$ & $28(17)$ & $55(17)$ & $6(5)$ & $15(8)$ & $15(21)$ \\
\hline & $301-500$ & $113(13)$ & $43(25)^{*}$ & $47(14)$ & $5(4)$ & $7(4)$ & $11(16)$ \\
\hline & $>500$ & $575(66)$ & $73(43)$ & $215(64)$ & $91(81)^{*}$ & $160(86)^{*}$ & $36(51)$ \\
\hline \multicolumn{2}{|c|}{ Does not do cosmetic treatments } & $94(11)$ & $14(8)$ & $30(9)$ & $8(7)$ & $28(15)^{*}$ & $14(20)^{*}$ \\
\hline \multicolumn{2}{|c|}{ Does not carry out botulinum toxin procedures } & $171(20)$ & $28(17)$ & $59(18)$ & $12(11)^{*}$ & $51(27)^{*}$ & $21(30)^{*}$ \\
\hline \multicolumn{2}{|c|}{ Only private consultations } & $171(20)$ & $22(13)^{*}$ & $87(26)^{*}$ & $23(20)$ & $17(9)^{*}$ & $22(31)^{*}$ \\
\hline \multicolumn{2}{|c|}{ Cost of consultation (R\$) } & $180(80)$ & $180(50)^{\mathrm{a}}$ & $200(135)^{\mathrm{b}}$ & $200(70)^{c}$ & $150(50)$ & $180(50)$ \\
\hline \multicolumn{8}{|c|}{ Median (interquartile deviation) } \\
\hline \multirow{3}{*}{$\begin{array}{l}\text { Scheduling time } \\
\text { (working days) }\end{array}$} & Insurance: Cosmetic & $6(14)$ & $7(15)$ & $7(18)$ & $7(18)$ & $5(8)^{\#}$ & $3(4)^{\#}$ \\
\hline & Insurance: Clinical & $7(16)$ & $7(21)$ & $7(20)$ & $9(23)$ & $6(8)^{*}$ & $3(18)^{\#}$ \\
\hline & Private: Cosmetic & $5(12)$ & $5(11)$ & $6(15)$ & $7(17)$ & $4(8)^{\#}$ & $3(4)^{\#}$ \\
\hline \multirow{2}{*}{$\begin{array}{l}\text { Median } \\
\text { (interquartile deviatior }\end{array}$} & Private: Clinical & $6(13)$ & $6(14)$ & $6(15)^{\#}$ & $8(17)$ & $5(7)^{\#}$ & $3(18)^{\#}$ \\
\hline & Botulinum Toxin & $5(11)$ & $5(10)$ & $5(15)$ & $6(16)$ & $5(8)^{\#}$ & $3(4)^{*}$ \\
\hline
\end{tabular}

* $\mathrm{p}<0,05$ in comparison with the other regions - Residue analysis

a $p<0,01$ (South vs Southeast and South vs Center-west);

b $\mathrm{p}<0,01$ (Southeast vs Northeast and Southeast vs North);

c $p<0,01$ (Center-west vs Northeast and Center-west vs North) - Generalized linear model.

\# $\mathrm{p}<0,05$ - in comparison with the other regions - Generalized linear model.

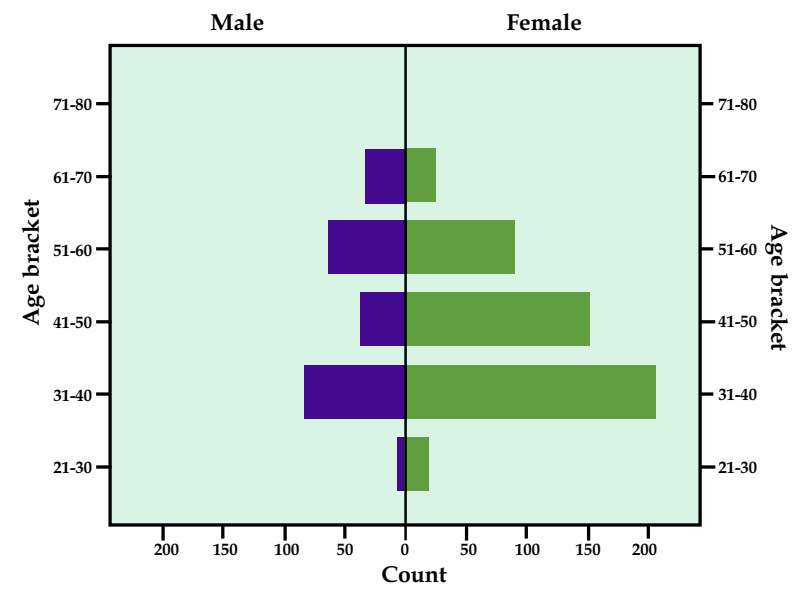

GrAPH 1: Diagram showing the distribution of sampled dermatologists in terms of gender and age bracket

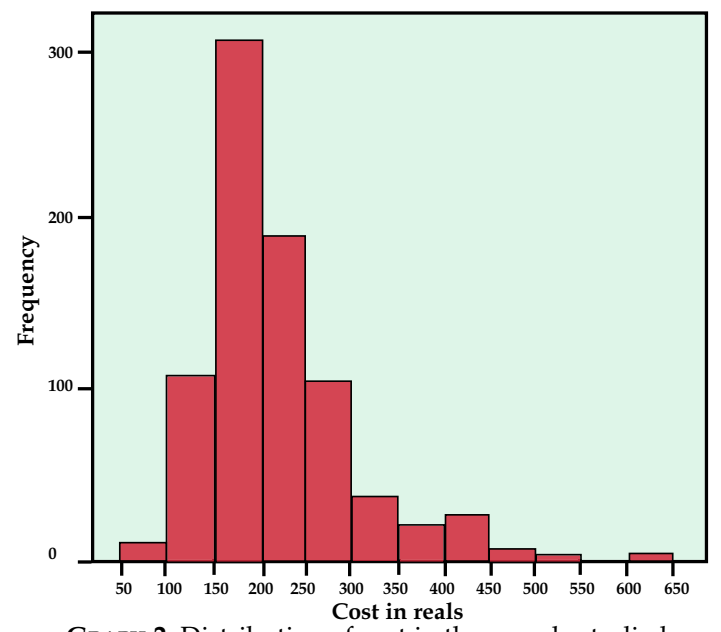

GrAPH 2: Distribution of cost in the sample studied 


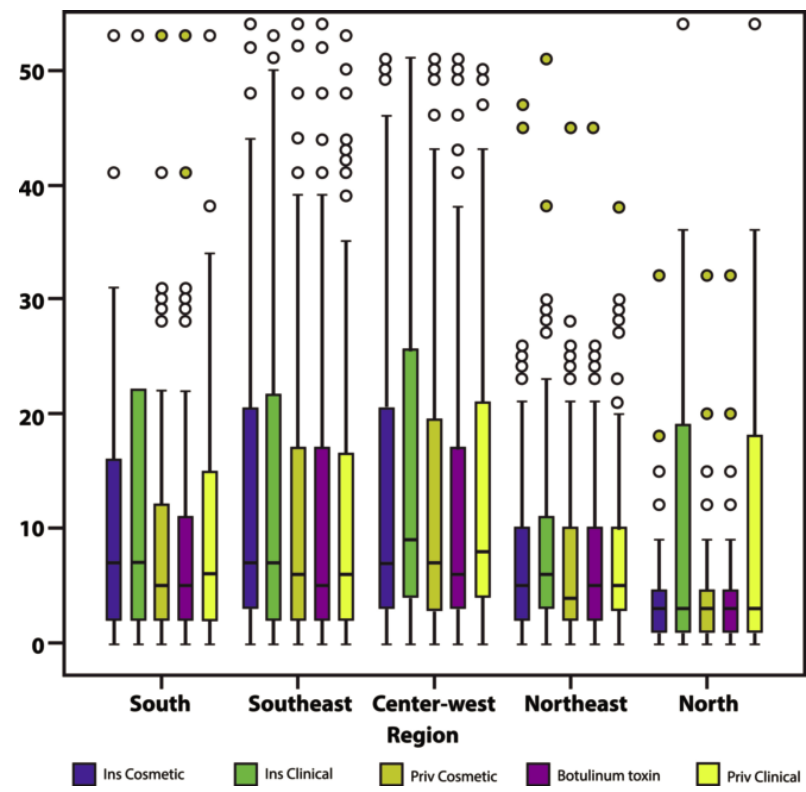

" $p$ (region) $<0,05$ (North and Northeast vs other regions) $p$ (type of consultation) $<0,05$ (Cons. clinical via insurance vs Cons. private clinical, Cons. private cosmetic and botulinum toxin) $p$ (Interaction region* type of consultation) $=0,86$.

GRAPH 3: Distribution of time (consecutive working days) for scheduling different types of consultations in different regions of the country

dures were scheduled more quickly than through insurance, regardless of whether they were cosmetic $(p<0,05)$, and irrespective of the region (Graph 3$)$.

There were longer waiting times for private consultations with female dermatologists, aged between 30 and 50, operating in cities with smaller populations, whose care was exclusively private and who did not carry out botulinum toxin procedures $(p<0,01)$.

Discarding dermatologists who dealt exclusively with clinical matters $(10.8 \%)$, and making adjustments in relation to the regions of the country, the scheduling times for private appointments did not differ between clinical and cosmetic consultations $(p=0,41)$, nor between the procedures (botulinum toxin) and private clinical consultations $(p=0,21)$. In the same way, scheduling times for clinical and cosmetic consultations were the same if both were arranged via insurance coverage $(p=0,43)$.

Dermatologists who work exclusively with private consultations reflect a different distribution pattern throughout the country's regions, carry out more botulinum toxin procedures $(88.9 \%)$, and have a preference for more populous cities (median: 1 million inhabitants). Their consultations are more expensive (median: R\$250) and their waiting times are shorter (median: 3 days) $(\mathrm{p}<0,05)$ (Table 2$)$.

\section{DISCUSSION}

The study outlined waiting times for scheduling private dermatological consultations in Brazil in 2011. Discrepancies emerged between waiting times, and factors relating to the medical consultations and dermatologists in different regions of the country.

The territorial area considered and the variability in demographic, ethnic and cultural density are not the only elements that explain the disparities in private dermatological cover. With irregular distribution of dermatologists, concentrated in metropolitan areas, economic realities in particular states might explain the greater purchasing power of individuals and thus, the larger market for private dermatological care. The fact that there are smaller densities of dermatologists in less developed states such as Acre, Amapá, Roraima, Rondônia, Maranhão and Piauí, in contrast to the great densities of the Federal District, São Paulo, Espírito Santo and Rio de Janeiro, adds weight to this argument. ${ }^{6-7}$

In the US, there is also a metropolitan distribution of professionals, with a lack of dermatologists in rural areas, which intensifies the discussion on what the right amount is to provide care for the population and the reasons for the poor distribution of professionals. ${ }^{4,5,12}$ The expansion of operations in terms of surgeries, laser and cosmetic treatments, has been identified as the main reason for the increased demand for dermatological services, leading to variation in state averages of 20 to 73 days for scheduling consultations., ${ }^{4,13-15}$ In the same way, waiting times to book consultations are shorter in places with higher population densities. The number of dermatologists who perform cosmetic care is also higher in these cities. ${ }^{13}$

Long waiting periods for booking consultations was the main factor some authors highlighted for the involvement of non-dermatologists in the domain, even leading to the hiring of professionals to undertake joint work in dermatological clinics in the US.,16

Nevertheless, the desire to qualify other medical professionals for the purposes of undertaking strictly cosmetic operations should be viewed as a desire to promote courses that are not SBD-certified and the invasion of professionals into dermatological practice. This insufficient training poses a potential risk to society. In Japan, over half the dermatological procedures have been delegated to non-dermatologists. ${ }^{17}$ It is beyond the scope of this study to gauge directly the impact of non-dermatologists but the reduction in waiting times for scheduling consultations is directly linked to this competition.

It is estimated that a waiting time of up to two weeks is appropriate for dermatological appointments and most of the consultations examined in this study fell within this period. ${ }^{13,15}$ However, there are 
examples among the sampled cities in provincial areas of average waiting times of over 20 working days, which demonstrates not the surplus of dermatologists but rather the irregular distribution across the territory, provoking a shortage in care for a significant proportion of the population.

In Canada, there are fewer than 1,000 dermatologists and, along with progressive urbanization, there are concerns over the lack of cover for retiring dermatologists, despite the impetus to hire foreign doctors. The time for scheduling a dermatological consultation is 5 to 10 weeks. ${ }^{15}$ Some governments have adopted teledermatology assistance programs and training of generalists as ways to address the gap..$^{18,19}$

Scheduling times vary greatly in Brazil but data show that private consultations and procedures are arranged quickly in comparison with appointments made via insurance, particularly those involving botulinum toxin procedures. These elements suggest that there is a difference between payment from medical insurance companies for consultations, and for procedures, which is why professionals opt for private appointments. North American studies have shown that scheduling times for botulinum toxin procedures, which are not covered by insurance, are on average half as long as for conventional appointments. There are also regional variations and relative differences in relation to the type of health insurance, in terms of waiting periods for scheduling consultations..$^{20,21}$

The developments noted in the new generation of dermatologists, like the greater proportion of female professionals holding the title of specialist, can help bring changes to the domain of dermatological coverage. There has been a reduction in the number of weekly clinical appointments, while recommended procedures have become more common, which could poten- tially widen the jobs market in the coming years. ${ }^{22}$

The methodology applied here does not allow for examination of the states' specificities or comparison between metropolitan and provincial regions. However, it paves the way for the widening of the sample to investigate local realities.

Equally, this study did not discuss public outpatient dermatological care (offered by SUS), which, even though it represents a smaller proportion of dermatological operations in the country, should be studied using a particular methodology, so as to gauge the need for dermatologists in a country with endemic areas of infectious dermatoses and that has seen a rise in basal cell carcinoma, melanoma and syphilis. ${ }^{23-27}$

The Brazilian Dermatology Society and its teaching committee should pay attention to the registration of residency places and work experience in areas with high concentrations of dermatologists, or that have shorter scheduling times for consultations, in order to preserve the members' jobs market and guarantee adequate care for the population.

Further, excellent accredited dermatological services could promote insurance agreements with teaching institutions in regions that lack professionals, in order to provide residency places for students of the domain.

\section{CONCLUSIONS}

There is great variation as regards dermatologists and scheduling times throughout the regions of the country. Private consultations and procedures are scheduled more quickly than with insurance. The SBD should focus on the span of the market and care for the population, in policies geared towards increasing the number of professionals and their distribution. $\square$ 


\section{REFERENCES}

1. Resneck J Jr. Too few or too many dermatologists? Difficulties in assessing optimal workforce size. Arch Dermatol. 2001;137:1295-301.

2. Brasil. Ministério da Saúde. Portaria $\mathrm{n}^{0} 1101$, de 12 de junho de 2002. Dispõe sobre os parâmetros assistenciais do Sistema Único de Saúde - SUS. Brasília: Ministério da Saúde; 2002.

3. Burns T, Breathnach S, Cox N, Griffiths C. Rook's Textbook of Dermatology. 8th ed Malden: Wiley-Blackwell; 2010. Chapter 1, Introduction and historical bibliography; p. 15

4. Kimball AB, Resneck JS Jr. The US dermatology workforce: a specialty remains in shortage. J Am Acad Dermatol. 2008;59:741-5.

5. Resneck J Jr, Kimball AB. The dermatology workforce shortage. J Am Acad Dermatol. 2004;50:50-4.

6. Mansur MC, Mansur J, Mansur L, Gonçalves BC, Pereira RN. Distribuição geográfica dos dermatologistas do Brasil em 1999: análise do mercado de trabalho em 13 anos. An Bras Dermatol. 2001;76:467-82.

7. Machado MH, Vieira LS, coords. Perfil dos dermatologistas no Brasil: relatório final (Brasil e grandes regiões). Rio de Janeiro: Sociedade Brasileira de Dermatologia; 2003.

8. IBGE.gob.br[Página na Internet]. Séries estatísticas \& Séries históricas [acesso em 02 ago 2012]. Disponível em: http://seriesestatisticas.ibge.gov.br/series.aspx?vcodigo=POP119.

9. Norman GR, Streiner DL. Biostatistics. The bare essentials. 3rd ed. Shelton, Connecticut: People's Medical Publishing House; 2008.

10. IBM SPSS Statistics Standard Campus Edition 20.0 for Windows. Statistical Package for Social Science (SPSS). 20 ed. Chicago (IL): SPSS Incorporation; 2011.

11. Miot HA. Tamanho da amostra em estudos clínicos e experimentais. J Vasc Bras 2011;10:275-8.

12. Uhlenhake $E$, Brodell R, Mostow $E$. The dermatology work force: a focus on urban versus rural wait times. J Am Acad Dermatol. 2009:61:17-22.

13. Suneja T, Smith ED, Chen GJ, Zipperstein KJ, Fleischer AB Jr, Feldman SR. Waiting times to see a dermatologist are perceived as too long by dermatologists: implications for the dermatology workforce. Arch Dermatol. 2001;137:1303-7.

14. Weingold DH, Lack MD. Appointment wait times for patients with changing moles. J Am Acad Dermatol. 2007;56:706-7.

15. Chow EY, Searles GE. The amazing vanishing Canadian dermatologist: results from the 2006 Canadian Dermatology Association member survey. J Cutan Med Surg. 2010;14:71-9.

16. Tsang MW, Resneck JS Jr. Even patients with changing moles face long dermatology appointment wait-times: A study of simulated patient calls to dermatologists. J Am Acad Dermatol. 2006;55:54-8.

17. Resneck JS Jr, Kimball AB. Who else is providing care in dermatology practices? Trends in the use of nonphysician clinicians. J Am Acad Dermatol. 2008;58:211-6.

18. Ogawa S, Isogawa N, Ushiro S, Ayuzawa J, Furue M. Dermatological legal claims in Japan. J Dermatol. 2008;35:426-32.

19. Miot HA, Paixão MP, Wen CL. Teledermatology - Past, present and future. An Bras Dermatol. 2005;80:523-32.

20. Miot HA. Desenvolvimento e sistematização da interconsulta dermatológica a distância. [tese]. São Paulo (SP): Faculdade de Medicina da Universidade de São Paulo; 2005.
21. Resneck JS Jr, Lipton S, Pletcher MJ. Short wait times for patients seeking cosmetic botulinum toxin appointments with dermatologists. J Am Acad Dermatol. 2007; 57:985-9.

22. Resneck J Jr, Pletcher MJ, Lozano N. Medicare, Medicaid, and access to dermatologists: the effect of patient insurance on appointment access and wait times. J Am Acad Dermatol. 2004;50:85-92.

23. Jacobson CC, Resneck JS Jr, Kimball AB. Generational differences in practice patterns of dermatologists in the United States: implications for workforce planning. Arch Dermatol. 2004;140:1477-82.

24. Chinem VP, Miot HA. Epidemiology of basal cell carcinoma. An Bras Dermatol. 2011;86:292-305

25. Nasser N. Cutaneous melanoma: a 30-year-retrospective epidemiological study conducted in a city in southern Brazil, from 1980-2009. An Bras Dermatol. 2011;86:932-41.

26. Schmitt JV, Chinem VP, Marques ME, Miot HA. Increase in the incidence of basal cell carcinoma in a university hospital between 1999 and 2009. An Bras Dermatol. 2011;86:375-7.

27. Penna GO, Domingues CM, Siqueira Jr JB, Elkhoury AN, Cechinel MP, Grossi MA, et al. Dermatological diseases of compulsory notification in Brazil. An Bras Dermatol. 2011; 86:865-77.

28. Miranda AE, Figueiredo NC, Pinto VM, Page K, Talhari S. Risk factors for syphilis in young women attending a family health program in Vitória, Brazil. An Bras Dermatol. 2012;87:76-83

How to cite this article: Miot HA, Miot LDB. Time needed to schedule dermatological consultations in Brazil. An Bras Dermatol. 2013;88(4):563-9. 